\title{
Project of a life-long education platform
}

\section{Laëtitia Lasagesse}

Laëtitia Lasagesse, "Project of a life-long education platform," Proc. SPIE 9664, Ninth International Topical Meeting on Education and Training in Optics and Photonics, 96641P (24 October 2005); doi: 10.1117/12.2207705 and Photonics, 2005, Marseille, France 


\title{
Ref ETOP044
}

\section{Project of a life-long education platform}

\author{
Laëtitia Lasagesse
}

\section{Abstract}

Opticsvalley proposes to present its project of a life-long education platform, with the objective to:

- gather training centres in the optics field

- exchange information on best practice and markets

- promote the life-long optics education offer

- present collective responses to the existing training needs

- foster interactions between training centres and optics industry representatives

\section{Summary}

Thanks to its continuous interaction with companies (large groups, SMEs and start-ups), with research and training centres, and with regional and local institutions, Opticsvalley has been in a perfect position to identify the needs for life-long education. This interaction revealed the lack of communication between industry representatives and training centres.

Opticsvalley is in the process of developing a life-long training platform, and is the leader of the project.

The platform involves the Paris Region training centres that offer optics training programmes, such as:

- $\quad$ Engineering Schools

- $\quad$ Universities

- $\quad$ Life-long training centres linked to other specialised organisations (e.g. Polytechnique)

The objective of such cooperation is to increase the visibility of and easy access to information regarding such life-long training programmes, and to better match the training programmes with the industry's needs.

So far, approximately 10 training centres have joined the project.

Opticsvalley's project comprises two activities:

- $\quad$ qualifying of the existing training programmes (markets, targets, training levels, etc)

and

- $\quad$ compiling a list of training needs from companies in the optics industry.

This work will allow Opticsvalley to identify the gap between the existing training programmes and industrial needs, hence to implement a cooperation strategy between training centres in order to fill the gap. 